\title{
Vibration Diagnostics of CNC Machining Center Spindle
}

\author{
Jozef Žarnovský ${ }^{1}$, Ivan Kováč ${ }^{1}$, Rastislav Mikuš ${ }^{1}$, Jiři Fries ${ }^{2}$, Matúš Mošat ${ }^{1}$ \\ ${ }^{1}$ Faculty of engineering, Slovak University of Agriculture in Nitra, Tr. A. Hlinku 2, 94976 Nitra, \\ E-mail: jozef.zarnovsky@uniag.sk \\ ${ }^{2}$ Faculty of Mechanical Engineering, Technical University of Ostrava, 17. listopadu 15/2172, 70833 Ostrava-Poruba, E- \\ mail: jiri.fries@vsb.cz
}

The principle of vibrodiagnostics lies in the appropriate measuring and analysis of mechanical vibrations of machinery and constructions in industrial and laboratory environment.

The aim of this paper is to perform diagnostic measurements on the most essential parts (spindles) of machinery devices Semico VCM 1000. Measurements were carried out by means of portable vibrodiagnostic measuring device Adash A4900 vibrio M. Vibrodiagnostic itself was realized as a walk-monitoring of machinery state according to corresponding technical standard ISO 10816-3:2009, and of limit values, which took place at regular intervals in the selected organization.

Keywords: Vibrations; diagnostics; spindle; device; speed

\section{Introduction}

Vibrodiagnostics represent an important tool for management of preventive maintenance of rotary machines, which can be realized using portable diagnostic measuring devices.[6]

Walk-measuring is characteristic by direct participation of the measuring technician, performing the measurements of vibrations in machinery, analyzing and evaluating them using diagnostic device by a measurement system. $[1,2,3]$

Monitoring is usually focused on stating the immediate technical state, it is not concerned with stating the reasons causing the changes in dynamic features of the machinery. Monitoring is primarily aimed at safety and protection of machinery. $[4,6,7,9]$

Devices and systems intended for monitoring of the technical state can simultaneously assess it and, in case of emergency, either alert the operators of the monitored machinery or automatically shut it down. Considering the significance of such decision-making, the monitoring systems should be selected, installed and operated in accordance with recommended technical standards. $[4,5,10,11]$

\section{Material and Methods}

Goal of the experiment was to carry out diagnostics, taking into account the vibrations in the most essential parts (spindles) of Semico VCM 1000 machinery. Measurements were performed by means of the measuring device Adash A4900 vibrio $M$. They were realized in a form of device walk-monitoring.

The obtained data were subsequently subjected to analysis, on the basis of which an evaluation of the technical condition of the machinery was carried out according to the relevant technical standard ISO 10816-3:2009 and limit values recommended by the Adash company.

\section{Characteristics of working machinery}

In terms of vibrations, two working devices of identical type were selected for experiment; these were CNC vertical machining centers SEMICO VMC 1000, located at a training center department in a select organization.

\section{SEMICO VMC 1000}

SEMICO VMC 1000 is a 3-axis vertical CNC machining center with rich equipment that meets the requirements for machining of precise parts with possibility of high-performance tool usage. Working device consists of a solid cast iron base, precision ball screws, high-quality electrical components provided by Siemens.

It includes Heidenhain iTNC 530 control system, allowing for simulating of production process directly on the control panel. Cooling of workpieces is realized by means of cooling emulsion supplied through the spindle under pressure of $30 \mathrm{Ba}[4,12]$.

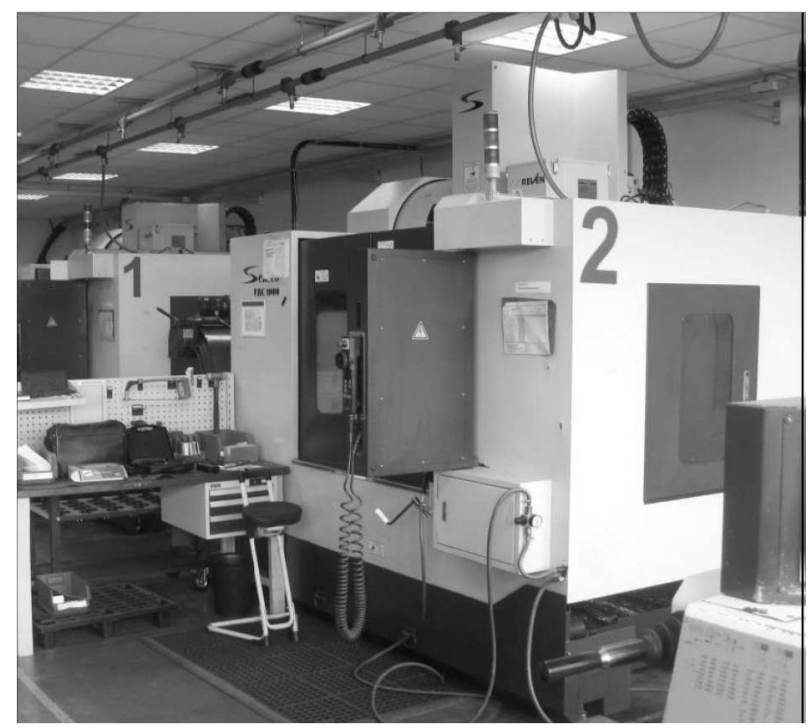

Fig. 1 Monitored CNC machining centers - SEMICO VMC 1000

Requirements for spindles of machining devices [2,4]:

- $\quad$ spindle operation precision - determined by radial and axial throws;

- Perfect control - spindle cannot change its position in regards of direction and sense of load; it 
must be possible to determine the clearance in bearings, which is a result of wear, for perfect control;

- Losses due to friction in bearings must be as low as possible in order to prevent warming;

- Spindle should be stiff in order to avoid changes in relative position between the device and workpiece - precision deterioration.

Causes of spindle malfunctions:

- machine overload;

- machine accident;

- machine imbalance;

- $\quad$ error in automatic tool change;

- inappropriate lubrication;

- poor cooling;

- leakage of cooling liquid in bearings;

- electric current passing through bearings;

- material fatigue.

It is possible to avoid occurrence of these malfunctions by careful machine inspection or regular monitoring of selected parameters, such as spindle vibration. Furthermore, selection of adequate lubrication and its regular replenishment also represent significant factors.[3,9]

\section{Properties of measuring device}

Portable diagnostic measuring device Adash A4900 vibrio $\mathrm{M}$ was utilized for measurement of machinery vibrations.

Portable diagnostic device allows performance of all essential vibrodiagnostic measurements, such as bearing state, lubrication and mechanical failures (misalignment, imbalance, mechanical loosening and resonances). It is possible to connect headphones to the device for listening to the vibration signal, what is highly useful in the diagnostics of gearboxes and slow rolling element bearings. $[2,4]$

It is possible to choose from a variety of measurement methods of vibration in machinery devices, with the evaluation of the technical state of the monitored devise based on these measurements. The device utilizes its own assessment software system DDS 2017 for analysis and evaluation of measurements. [4]

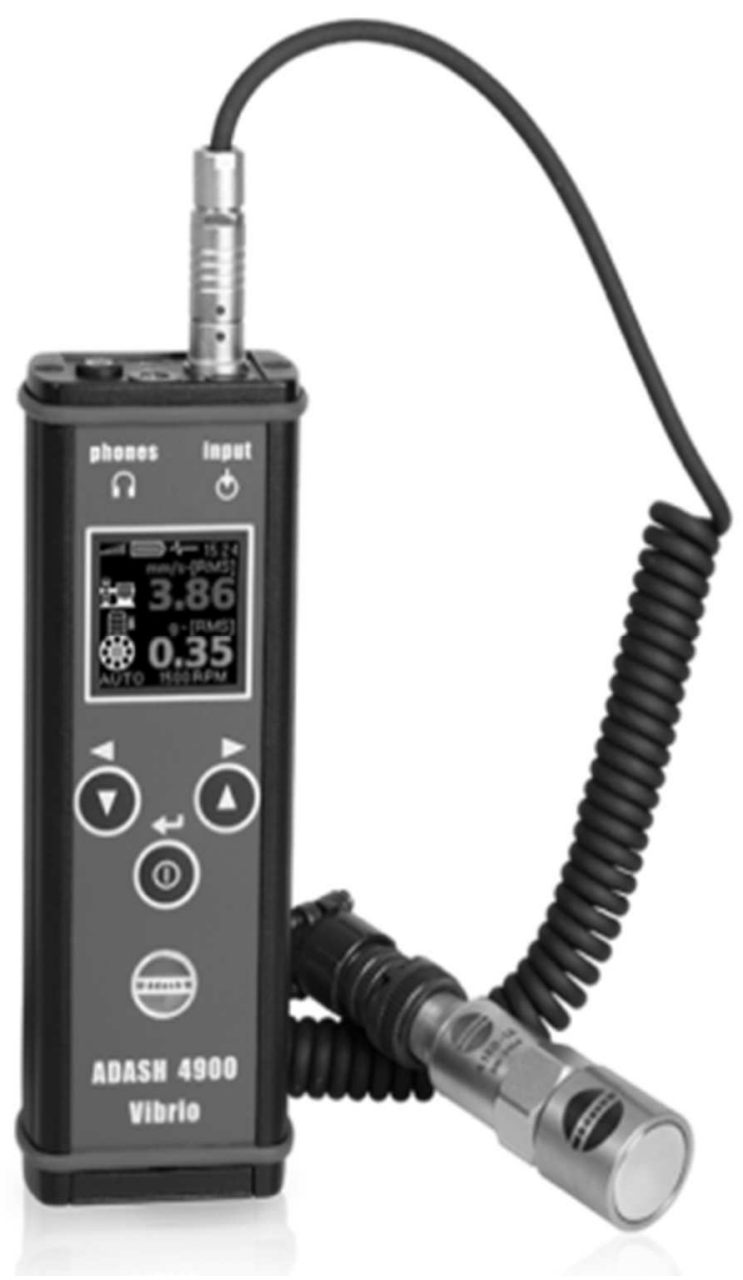

Fig. 2 Vibrodiagnostic device - Adash A4900 vibrio M

Measuring device Adash A4900 vibrio M contains standards STN ISO 10816-3 (Tab.1), as well as values provided by Adash company for vibration limit assessment. These limit values provided by Adash company are not based directly on any existing standards, but are a result of 20 years of experience of engineers who have designed, tested and produce the tools and programs in the Adash company (Figs. 3,4).

Tab. 1 Limit values of vibration magnitude in machinery (STN ISO 10816-3) [8]

\begin{tabular}{|c|c|c|c|c|c|c|}
\hline Group & Sub-group & Border zone A & Border zone B & Border zone C & Border zone D & Vef \\
\hline \multirow{2}{*}{1} & Rigid rotor & $<2.3$ & $2.3-4.5$ & $4.5-7.1$ & $>7.1$ & $(\mathrm{~mm} / \mathrm{s})$ \\
\cline { 2 - 7 } & Flexible rotor & $<3.5$ & $3.5-7.1$ & $7.1-11.0$ & $>11.0$ & $(\mathrm{~mm} / \mathrm{s})$ \\
\hline \multirow{2}{*}{2} & Rigid rotor & $<1.4$ & $1.4-2.8$ & $2.8-4.5$ & $>4.5$ & $(\mathrm{~mm} / \mathrm{s})$ \\
\cline { 2 - 7 } & Flexible rotor & $<2.3$ & $2.3-4.5$ & $4.5-7.1$ & $>7.1$ & $(\mathrm{~mm} / \mathrm{s})$ \\
\hline \multirow{3}{*}{3} & Rigid rotor & $<2.3$ & $2.3-4.5$ & $4.5-7.1$ & $>7.1$ & $(\mathrm{~mm} / \mathrm{s})$ \\
\cline { 2 - 7 } & Flexible rotor & $<3.5$ & $3.5-7.1$ & $7.1-11.0$ & $>11.0$ & $(\mathrm{~mm} / \mathrm{s})$ \\
\hline \multirow{2}{*}{4} & Rigid rotor & $<1.4$ & $1.4-2.8$ & $2.8-4.5$ & $>4.5$ & $(\mathrm{~mm} / \mathrm{s})$ \\
\cline { 2 - 7 } & Flexible rotor & $<2.3$ & $2.3-4.5$ & $4.5-7.1$ & $>7.1$ & $(\mathrm{~mm} / \mathrm{s})$ \\
\hline
\end{tabular}


Graphs below show the limit values of the vibration velocity and vibration acceleration depending on the machine provided by Adash Company [4].

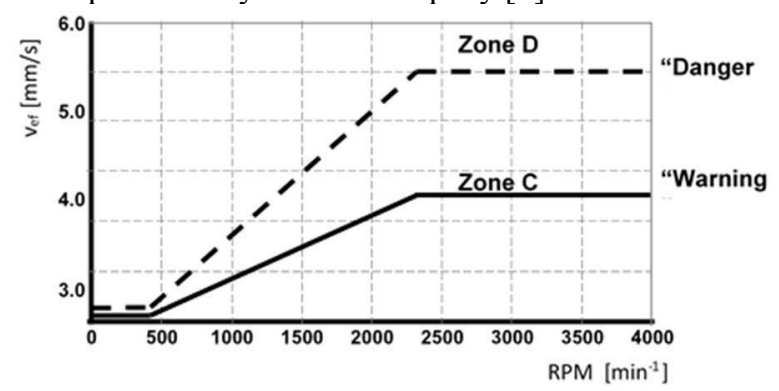

Fig. 3 Limit values of vibration velocity [4]

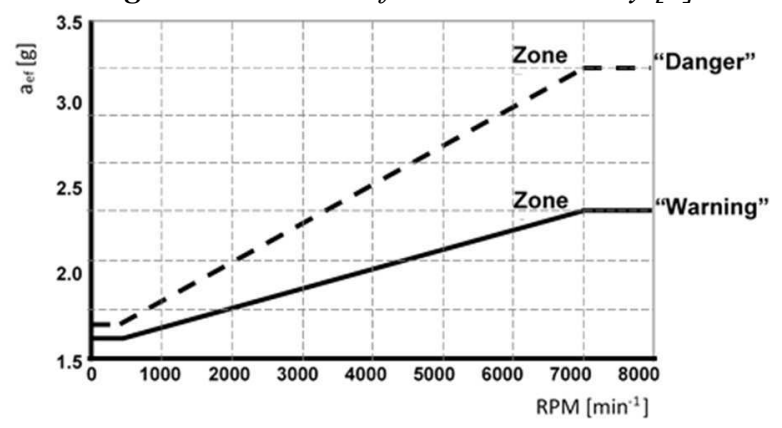

Fig. 4 Limit values of vibration acceleration [4]

\section{Measurement characteristics}

Diagnostics of vibrations were performed as walkmonitoring at regular intervals in the select organization.

Observed vibration parameters included vibration velocity and vibration acceleration, for which the following methods were used:

- vibration magnitude measurement;

- vibration acceleration envelope measurement.

\section{Method of vibration measurement}

Before the measurements, it was necessary to fix the measuring pad in the bearing area of rolling bearings located in machinery spindles using a two-component epoxy adhesive. In order to position the measuring pad in the area of the spindle rolling bearings, we proceeded according to the spindle technical drawing. In such manner, we ensured that vibration will be measured in the very same place during the entire walk-monitoring of ma- chinery, as well as adequate attachment of external piezoelectric vibration sensors.

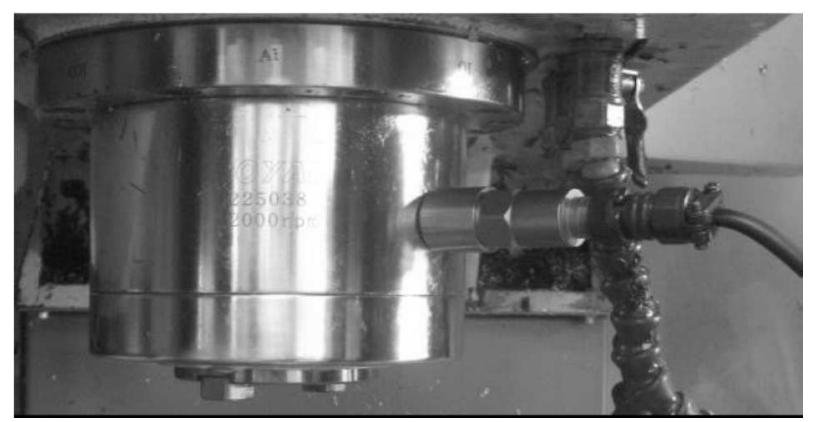

Fig. 5 Fixing of piezoelectric vibration senors

Subsequently, it was necessary to allow access to the measuring device during operation, as CNC machining centre SEMICO VMC 1000 is equipped with locking system. This meas that it is not possible to open the safety door or inspection door during machine operation. Therefore, it was necessary to disassemble the safety-switch fastened to the inspection door.

During the course of measurements, vibration monitoring took place at the identical operational conditions vibrations were measured without using a device in order to achieve maximum spindle balance. Measurements were carried out at individual machinery speeds: 1,000; 3,$000 ; 6,000 ; 9,000 ; 12,000 \mathrm{rpm}$. Measurements were performed three times for each individual speed and acceleration; and average values from individulal vibration velocities and vibration accelaration values were calculated. Spindle was stopped after each measurement and subsequently restarted. In order to accelerate the measurement process, the organization's technician created a program sequence for the machine, which subsequently automatically switched on the spindle, stopped it and changed its speed. The average obtained data were recorded in tables.

\section{Results and discussion}

\section{Average values of vibration velocities $-\overline{\boldsymbol{v}}_{\text {ef }}$}

Table 2 shows average vibration velocity values at individual machinery speeds observed (10 measurements) during walk-monitoring.

Tab. 2 Vibration velocities at individual spindle speeds for machines no. 1 and 2.

\begin{tabular}{|c|c|c|c|c|c|c|c|c|c|c|}
\hline RPM & \multicolumn{2}{|c|}{1000} & \multicolumn{2}{|c|}{3000} & \multicolumn{2}{|c|}{6000} & \multicolumn{2}{|c|}{9000} & \multicolumn{2}{|c|}{12000} \\
\hline Machine & no. 1 & no. 2 & no. 1 & no. 2 & no. 1 & no. 2 & no. 1 & no. 2 & no. 1 & no. 2 \\
\hline$\overline{\boldsymbol{v}}_{\text {ef }}$ & {$[\mathrm{mm} / \mathrm{s}]$} & {$[\mathrm{mm} / \mathrm{s}]$} & {$[\mathrm{mm} / \mathrm{s}]$} & {$[\mathrm{mm} / \mathrm{s}]$} & {$[\mathrm{mm} / \mathrm{s}]$} & {$[\mathrm{mm} / \mathrm{s}]$} & {$[\mathrm{mm} / \mathrm{s}]$} & {$[\mathrm{mm} / \mathrm{s}]$} & {$[\mathrm{mm} / \mathrm{s}]$} & {$[\mathrm{mm} / \mathrm{s}]$} \\
\hline 1. & 0.055 & 0.176 & 0.096 & 0.296 & 0.462 & 0.525 & 1.176 & 0.991 & 3.271 & 1.933 \\
\hline 2. & 0.055 & 0.170 & 0.097 & 0.290 & 0.466 & 0.534 & 1.183 & 0.969 & 3.226 & 1.957 \\
\hline 3. & 0.056 & 0.172 & 0.095 & 0.292 & 0.459 & 0.540 & 1.189 & 0.974 & 3.184 & 1.932 \\
\hline 4. & 0.056 & 0.172 & 0.096 & 0.294 & 0.465 & 0.537 & 1.173 & 0.978 & 3.279 & 1.916 \\
\hline 5. & 0.054 & 0.174 & 0.096 & 0.294 & 0.471 & 0.543 & 1.169 & 0.992 & 3.293 & 1.950 \\
\hline 6. & 0.056 & 0.170 & 0.098 & 0.290 & 0.462 & 0.536 & 1.177 & 0.978 & 3.244 & 1.929 \\
\hline 7. & 0.054 & 0.173 & 0.097 & 0.286 & 0.463 & 0.535 & 1.189 & 0.969 & 3.250 & 1.928 \\
\hline 8. & 0.056 & 0.170 & 0.099 & 0.293 & 0.468 & 0.525 & 1.167 & 0.971 & 3.174 & 1.956 \\
\hline 9. & 0.056 & 0.170 & 0.097 & 0.290 & 0.464 & 0.530 & 1.211 & 0.973 & 3.255 & 1.931 \\
\hline 10. & 0.056 & 0.175 & 0.096 & 0.288 & 0.462 & 0.543 & 1.191 & 0.992 & 3.250 & 1.944 \\
\hline
\end{tabular}


From the analyses of vibration velocities, it is possible to conclude that all measured vibration velocity values of machine no. 1 are in zone $\mathrm{C}$. Other measured vibration velocity values of machines no. 1 and 2 are in zones A to B. Division of these zones is given in Table 1 .
Table 3 defines minimum and maximum and weighted arithmetic mean values of vibration velocities at individual machinery speeds that were calculated from all values observed.

Tab. 3 Mean vibration velocity values

\begin{tabular}{|c|c|c|c|c|c|c|c|c|c|c|}
\hline RPM & \multicolumn{2}{|c|}{$\mathbf{1 0 0 0}$} & \multicolumn{2}{c|}{$\mathbf{3 0 0 0}$} & \multicolumn{2}{c|}{$\mathbf{6 0 0 0}$} & \multicolumn{2}{c|}{$\mathbf{9 0 0 0}$} & \multicolumn{1}{c|}{12000} \\
\hline $\begin{array}{c}\text { Ma- } \\
\text { chine }\end{array}$ & no. 1 & no. 2 & no. 1 & no. 2 & no. 1 & no. 2 & no. 1 & no. 2 & no. 1 & no. 2 \\
\hline Vef & {$[\mathbf{m m} / \mathbf{s}]$} & {$[\mathbf{m m} / \mathbf{s}]$} & {$[\mathbf{m m} / \mathbf{s}]$} & {$[\mathbf{m m} / \mathbf{s}]$} & {$[\mathbf{m m} / \mathbf{s}]$} & {$[\mathbf{m m} / \mathbf{s}]$} & {$[\mathbf{m m} / \mathbf{s}]$} & {$[\mathbf{m m} / \mathbf{s}]$} & {$[\mathbf{m m} / \mathbf{s}]$} & {$[\mathbf{m m} / \mathbf{s}]$} \\
\hline min. & 0.053 & 0.168 & 0.094 & 0.284 & 0.446 & 0.516 & 1.149 & 0.947 & 3.114 & 1.894 \\
\hline max. & 0.057 & 0.177 & 0.099 & 0.302 & 0.483 & 0.552 & 1.218 & 1.005 & 3.335 & 1.986 \\
\hline WAM & 0.055 & 0.172 & 0.097 & 0.291 & 0.464 & 0.535 & 1.183 & 0.979 & 3.243 & 1.935 \\
\hline
\end{tabular}

Mean vibration velocity values (Table 3 ) are graphically depicted in Fig 6; moreover, measured vibrations are compared to limit velocity values according to standard STN ISO 10816-3 (in accordance with Table 1).

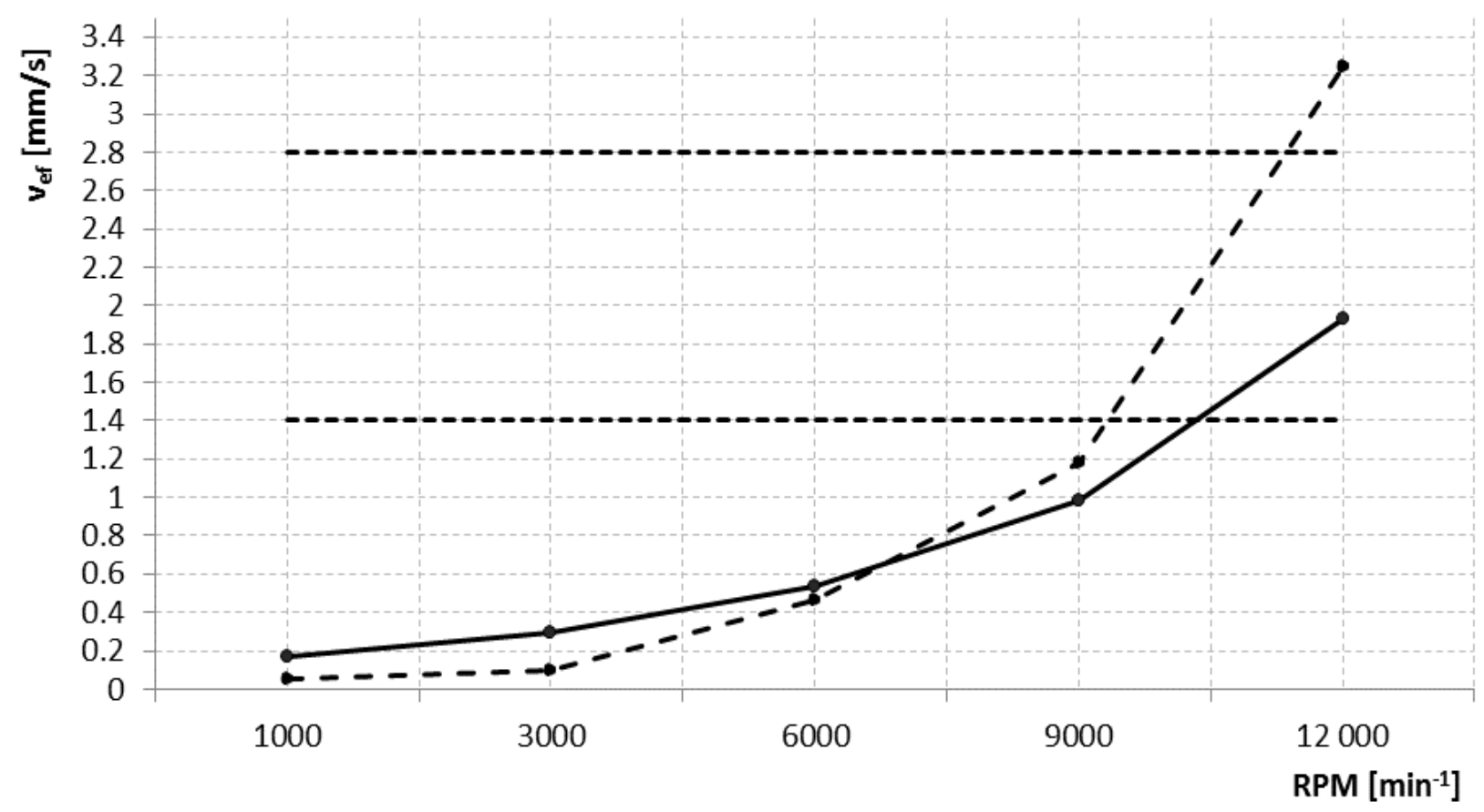

- - Machine no. $1 \longrightarrow$ Machine no. 2 -----Border zone A/B

----Border zone B/C

Fig. 6 Graphical dependence of vibration velocities (STN ISO 10816-3).

As is evident from Fig. 6, mean vibration velocity values at $1000-9000 \mathrm{rpm}$ are in zone A for both machines, indicating good technical condition. Mean vibration velocity values at $12,000 \mathrm{rpm}$ of machine no. 2 is in zone $\mathrm{B}$, signifying serviceable condition in uninterrupted operation. Values of machine no. 1 at the very same revulsions are in zone $\mathrm{C}$, indicating serviceable condition in limited operation.

\section{Comparison of vibration velocity with values given by Adash company}

Graphical dependence of machinery vibrations (Fig.
7) was plotted on the basis of mean vibration velocity values (Fig. 3), which was compared with limit vibration velocity values recommended by Adash company (compare with Fig. 3).

Comparison of measured values with limit values defined by Adash company differs from comparison with the standard STN ISO 10816-3 in the fact that values recommended by Adash are defined on the basis of machinery velocity. In regards to Fig. 7 , it is possible to conclude that alert threshold was exceeded merely by machine no. 1 at $12,000 \mathrm{rpm}$. This means that operators should pay more attention to machine condition, as this issue can result in future machine malfunction. 


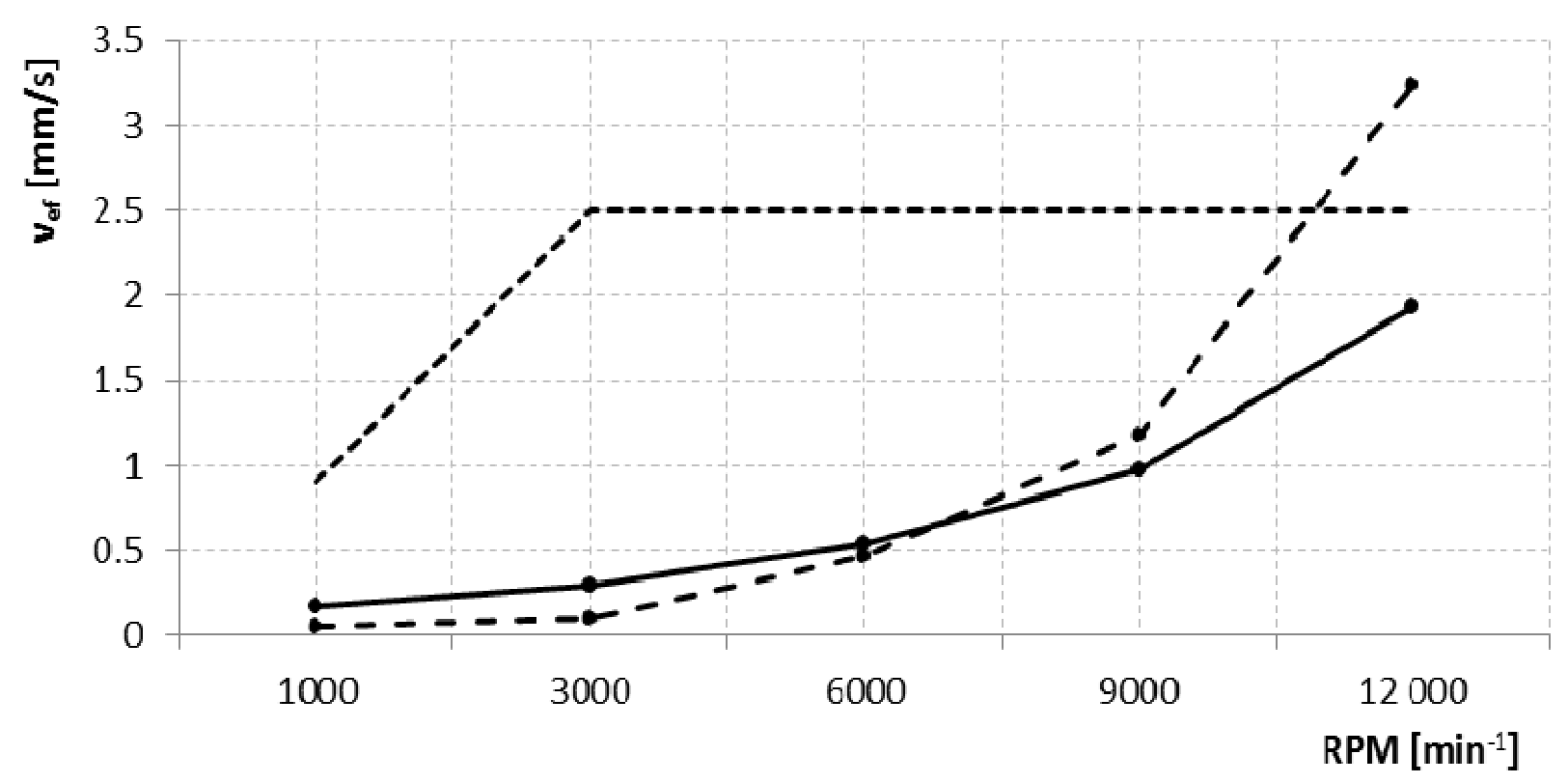

$-\rightarrow$ Machine no. $1 \longrightarrow$ Machine no. $2----\not$ Warning

Fig. 7 Graphical dependence of vibration velocity (Adash)

\section{Average vibration acceleration values $-\overline{\boldsymbol{a}}_{\mathrm{ef}}$}

Table 4 shows average vibration acceleration values at individual machinery speeds observed during walkmonitoring.

Tab. 4 Measured vibration acceleration values

\begin{tabular}{|c|c|c|c|c|c|c|c|c|c|c|}
\hline RPM & \multicolumn{2}{|c|}{1000} & \multicolumn{2}{|c|}{3000} & \multicolumn{2}{|c|}{6000} & \multicolumn{2}{|c|}{9000} & \multicolumn{2}{|c|}{12000} \\
\hline Machine & no. 1 & no. 2 & no. 1 & no. 2 & no. 1 & no. 2 & no. 1 & no. 2 & no. 1 & no. 2 \\
\hline$\overline{\boldsymbol{a}}_{\text {ef }}$ & {$[\mathrm{mm} / \mathrm{s}]$} & {$[\mathrm{mm} / \mathrm{s}]$} & {$[\mathrm{mm} / \mathrm{s}]$} & {$[\mathrm{mm} / \mathrm{s}]$} & {$[\mathrm{mm} / \mathrm{s}]$} & {$[\mathrm{mm} / \mathrm{s}]$} & {$[\mathrm{mm} / \mathrm{s}]$} & {$[\mathrm{mm} / \mathrm{s}]$} & {$[\mathrm{mm} / \mathrm{s}]$} & {$[\mathrm{mm} / \mathrm{s}]$} \\
\hline 1. & 0.062 & 0.055 & 0.087 & 0.125 & 0.155 & 0.185 & 0.213 & 0.253 & 0.328 & 0.500 \\
\hline 2. & 0.062 & 0.053 & 0.087 & 0.123 & 0.155 & 0.186 & 0.211 & 0.252 & 0.336 & 0.509 \\
\hline 3. & 0.063 & 0.053 & 0.087 & 0.125 & 0.152 & 0.185 & 0.214 & 0.252 & 0.335 & 0.503 \\
\hline 4. & 0.063 & 0.052 & 0.087 & 0.124 & 0.154 & 0.184 & 0.210 & 0.258 & 0.335 & 0.509 \\
\hline 5. & 0.061 & 0.054 & 0.086 & 0.124 & 0.153 & 0.187 & 0.212 & 0.260 & 0.335 & 0.508 \\
\hline 6. & 0.063 & 0.052 & 0.087 & 0.125 & 0.156 & 0.185 & 0.211 & 0.261 & 0.333 & 0.501 \\
\hline 7. & 0.061 & 0.054 & 0.088 & 0.126 & 0.155 & 0.184 & 0.212 & 0.259 & 0.344 & 0.512 \\
\hline 8. & 0.063 & 0.051 & 0.087 & 0.128 & 0.155 & 0.184 & 0.213 & 0.260 & 0.338 & 0.511 \\
\hline 9. & 0.063 & 0.051 & 0.087 & 0.126 & 0.156 & 0.186 & 0.214 & 0.260 & 0.343 & 0.510 \\
\hline 10. & 0.063 & 0.054 & 0.086 & 0.126 & 0.156 & 0.183 & 0.212 & 0.259 & 0.340 & 0.501 \\
\hline
\end{tabular}

In relation to analyses of vibration acceleration values at individual machinery speeds, it is possible to conclude that all measured acceleration values at specific speeds were in the same zone, with minimum deviations.
Comparison of vibration acceleration values with values provided by the Adash company

Table 5, showing dependence of machinery vibration, was plotted on the basis of mean vibration acceleration values, which were compared with limit vibration velocity values recommended by the Adash company.

Tab. 5 Analysis of vibration acceleration from all measured values

\begin{tabular}{|c|c|c|c|c|c|c|c|c|c|c|}
\hline RPM & \multicolumn{2}{|c|}{$\mathbf{1 0 0 0}$} & \multicolumn{2}{c|}{$\mathbf{3 0 0 0}$} & \multicolumn{2}{c|}{$\mathbf{6 0 0 0}$} & \multicolumn{2}{c|}{ 9000 } & \multicolumn{2}{c|}{$\mathbf{1 2 0 0 0}$} \\
\hline Machine & no. 1 & no. 2 & no. 1 & no. 2 & no. 1 & no. 2 & no. 1 & no. 2 & no. 1 & no. 2 \\
\hline aef & {$[\mathbf{g}]$} & {$[\mathbf{g}]$} & {$[\mathbf{g}]$} & {$[\mathbf{g}]$} & {$[\mathbf{g}]$} & {$[\mathbf{g}]$} & {$[\mathbf{g}]$} & {$[\mathbf{g}]$} & {$[\mathbf{g}]$} & {$[\mathbf{g}]$} \\
\hline min. & 0.060 & 0.051 & 0.084 & 0.121 & 0.150 & 0.180 & 0.206 & 0.244 & 0.322 & 0.484 \\
\hline max. & 0.064 & 0.056 & 0.089 & 0.129 & 0.159 & 0.189 & 0.218 & 0.268 & 0.347 & 0.528 \\
\hline WAM & 0.062 & 0.053 & 0.087 & 0.125 & 0.155 & 0.185 & 0.212 & 0.257 & 0.336 & 0.506 \\
\hline
\end{tabular}



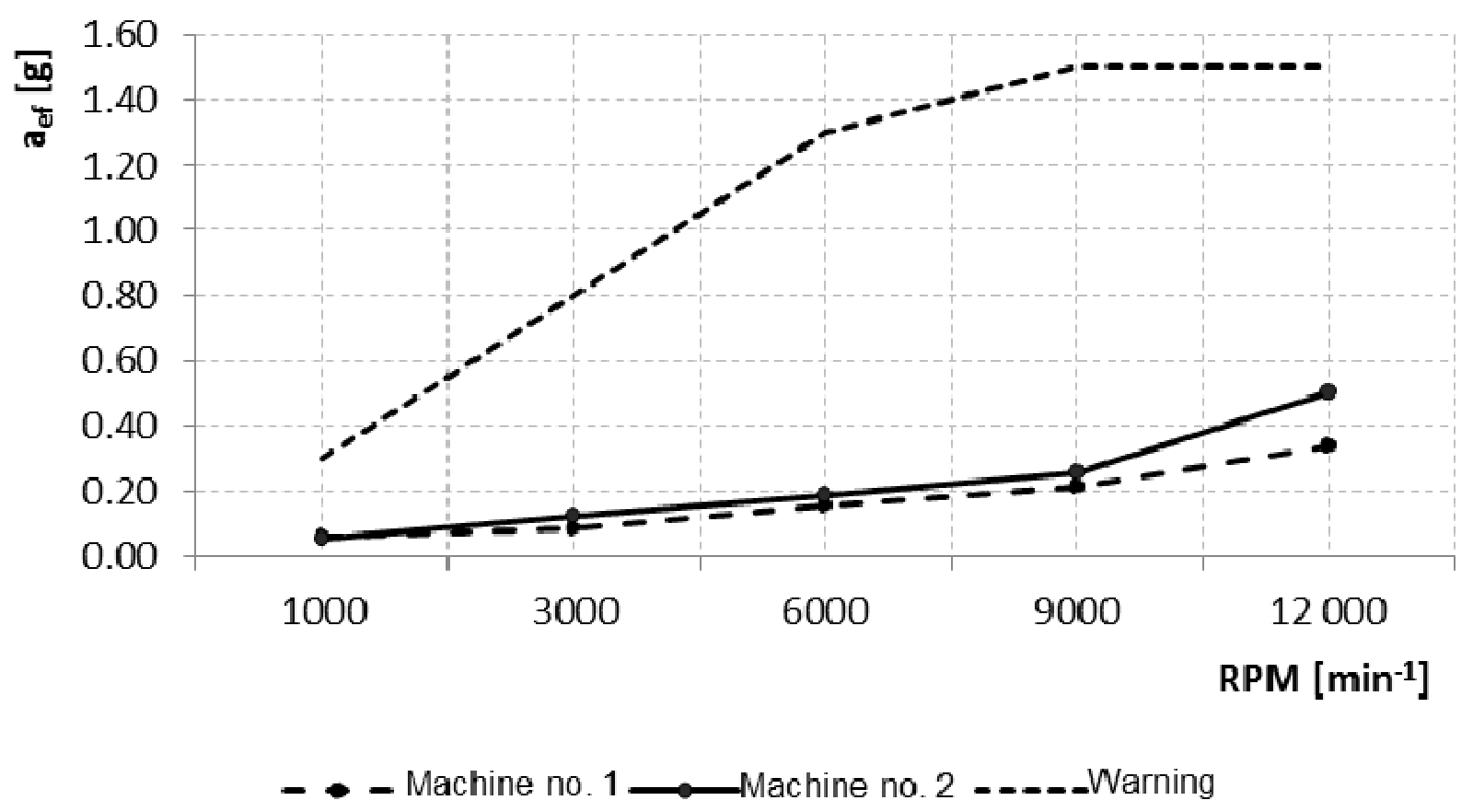

Fig. 8 Graphical dependence of vibration acceleration.

In this case, the comparison of vibration acceleration is similarly carried out on the basis of limit values dependent on the revulsions of the machinery recommended by Adash. From the Fig. 8, it is clear that the alert threshold was not exceeded by any of the observed machines. On the basis of this finding it can be stated that the technical state of the rolling bearings is sufficient from the point of view of the vibration acceleration and the machine can be used in operation.

\section{Conclusion}

The magnitude of vibrations on the most relevant parts of the SEMICO VMC 1000 machinery, i.e. the spindle, were evaluated by means of observation of specific parameters, carried out in form of walk-monitoring in a select organization.

From the results of measuring the vibrations by means of diagnostic device Adash A4900 vibrio M, we can state that the average values of the vibration velocity of the machine no. 1 were in the zones A to B, meaning suitable state in continuous operation. At maximum revulsions $(12,000 \mathrm{rpm})$, the average value of the vibration velocity was in the zone $\mathrm{C}$, thus exceeding the $\mathrm{B} / \mathrm{C}$ threshold, representing a suitable state in case of intermittent operation. On the basis of these findings, technical state of the spindle of the machinery no. 1 was evaluated as sufficient with limitations, similarly to the spindle of machinery no. 2 , as these were machines operating in a limited regime.

Similarly, in establishing the average values of the vibration acceleration of the machines no. 1 and 2, it can be concluded that the technical state of the diagnosed rolling bearings located in the bottom part of the spindles of the machines is sufficient from this point of view.

Observation of vibrations on the machinery belongs among the most important activities securing th proper and uninterrupted performance of the machinery, not only from economic standpoint, but also that of security.

Monitoring of technical state of machinery is the key to revealing of damaged parts, thus preventing unexpected malfunctions and breakdowns of machines used in production.

\section{Acknowledgement}

The study was supported by projects VEGA no. 1/0718/17 Study about the effect of technological parameters of the surface coating in agricultural and forestry techniques for qualitative parameters, safety and environmental acceptability.

\section{References}

[1] BLATA, J., ŠEDĚNKA, D., KAŠIAR, L., VOLNA, P. (2017). Examining the condition of the ball and the ball track on the heavy machine ZP6600. In: Diagnostyka. Varšava: Polish Society of Technical Diagnostics, 2017, 18(3), pp. 85-91. ISSN 1641-6414.

[2] BLATA, J. (2010). Metody technické diagnostiky. 1 ed. Ostrava Vysoká škola báňská - Technická univerzita v Ostrave, 2010. 27 pp. ISBN 978-80248-2735-3

[3] MONI, V., BLATA, J., CYMERYS, D., RIPEL, J. (2014). Practical application of the new MMM method in non-destructive testing. SGEM 2014: 14th international multidisciplinary scientific geoconference: GeoConference on Ecology, Economics, Education and Legislation. Volume III, Environmental economics, 2014, Albena, Bulgaria. 
STEF92 Technology Ltd., 2014, 14(3), pp. 451456. ISSN 1314-2704.

[4] MOŠAŤ M. (2017). Diagnostika a analýza vibrácií strojných zariadení. Diplomová práca. Slovenská pol'nohospodárska univerzita v Nitre, 2017.

[5] PANDA, A., PRISLUPČÁK, M., JURKO, J., PANDOVÁ, I., MRKVICA, I., LUSCINSKI, S. (2016). The Impact of Vibration on the Technological Head. In: Manufacturing technology, 2016, J. E. Purkyne University in Usti nad Labem, Vol. 16, No. 3 ISSN 1213-2489.

[6] PEŤKOVÁ, V. (2010). Teória a aplikácia vybraných metód technickej diagnostiky. TUKE 2010, 234 s. ISBN 978-80-553-0483-0

[7] ŠEDĚNKA, D., BLATA, J., KAŠIAR, L., HEISIG, L., ŽÁRSKÝ, V. (2017). Deployment of technical diagnostics during commissioning of small pumped storage hydropower plant. In: SGEM 2017: Proceedings of the 17th International Multidisciplinary Scientific GeoConference: 2017, Albena, Bulgaria. Volume 17. Issue 54. Sofia: STEF92 Technology Ltd., 2017. pp. 175-182. ISBN 978-619-7408-11-9.

[8] STN ISO 10816-3: (2010). Mechanické kmitanie. Hodnotenie kmitania strojov meraním na nerotuj- úcich častiach. Čast' 3: Priemyselné stroje s menovitým výkonom nad $15 \mathrm{~kW} \mathrm{~s}$ menovitými otáčkami od 120 min-1 do 15000 min-1 pri meraní v mieste trvalého uloženia.

[9] ŽARNOVSKÝ, J., KOVÁČ, I., KROČKO, V., HEGEDUŠ, P. (2015). Vibrodiagnostics in use of monitoring the technical condition of cars. In: DIAGO 2015. Ostrava: Vysoká škola báňská - Technická univerzita. (2015), pp. 348354. ISSN 1210-311X.

[10] ZASADZIEŃ, M. (2012). An analysis of reliability indexes of the key machinery in a selected production enterprise. In: DIAGO 2016. Technická diagnostika strojů a výrobních zařízení. Ostrava 1. Vysoká škola báňská - Technická univerzita, ISSN 1210-311X 2012. p. 56.

[11] ZASADZIEN' M. (2013). An analysis of the failure frequency of machines in an enterprise characterised by a changeable production level. Scientific Journals Maritime University of Szczecin, 34, 2013. ISSN 1733-8670, pp. 103-107.

[12] ZHUN WANG. (2018). Research on the Design of a Mill-turn Center. In: Manufacturing technology, 2018, J. E. Purkyne University in Usti nad Labem, 2018 Vol. 18, No. 1, ISSN 1213-24891 